\section{Perioperative Complications and Concomitant Diseases of Patients Followed in Intensive Care Unit After Cleft Lip-Palate Surgery}

\author{
Yarık Damak-Dudak Cerrahisi Sonrası Yoğun \\ Bakım Ünitesinde Takip Edilen Hastaların \\ Perioperatif Komplikasyonları ve Eşlik Eden \\ Hastalıkları
}

Murat Tümer (1)

Ayşe Ayyıldız (1)

Başak Akça ®

Aysun Ankay Yılbaş $\circledast$

Filiz Üzümcügil ()

Özgür Canbay (1)

\begin{abstract}
Objective: Patients with cleft lip/palate (CLCP) might need postoperative care in Intensive Care Unit (ICU) due to several reasons like difficult airway management, associated abnormalities and perioperative respiratory complications. Our aim was to evaluate the factors associated with difficult airway and need for postoperative ICU follow-up in patients with CLCP operated in our institution.

Method: Patients with CLCP followed up postoperatively in ICU between 2005-2013 were retrospectively reviewed.

Results: Twenty patients were included to the study. Ten patients had CLCP, and 10 cases had isolated cleft palate. Difficult intubation was seen in 8 patients. Difficult mask ventilation was seen only in one patient with $22 q 11$ deletion. All patients with difficult intubation had micrognathia. Nasal fiberoptic bronchoscopy was more commonly used in patients with difficult intubation. There was a statistically significant relationship between the presence of any systemic disease and difficult intubation. Main reasons for ICU follow-up were the need for close monitoring and airway related problems.

Conclusion: Difficult airway is a frequent problem in patients with CLCP even in the absence of a diagnosed syndrome. Patients with difficult airway or risk of postoperative airway obstruction could be better followed in ICU during early postoperative period for rapid diagnosis and treatment of possible complications by experienced staff.
\end{abstract}

Keywords: Airway management, pediatric anesthesia, cleft lip and palate

öz

Amaç: Yarık dudak/damak (YDD) hastaları zor hava yolu yönetimi, eşlik eden anomaliler ve solunum komplikasyonları gibi çeşitli nedenlerden dolayı postoperatif dönemde Yoğun Bakım Ünitesinde (YBÜ) bakıma ihtiyaç duyabilirler. Amacımız, kurumumuzda opere edilen YDD'li hastalarda zor hava yolu ve postoperatif YBÜ takibine duyulan ihtiyaç ile ilişkili faktörleri değerlendirmektir.

Yöntem: 2005-2013 yılları arasında YBÜ'de ameliyat sonrası takip edilen YDD hastaları retrospektif olarak incelendi.

Bulgular: Yirmi hasta çalışmaya dahil edildi. On hastada yarık damak ve dudak birlikteyken, on hastada izole yarık damak vardı. Sekiz hastada zor entübasyon görüldü. Zor maske ventilasyonu sadece $22 q 11$ delesyonu olan bir hastada görüldü. Entübasyonu zor olan tüm hastalarda mikrognati vardı. Nazal fiberoptik bronkoskopi zor entübasyonu olan hastalarda daha sık kullanıldı. Herhangi bir sistemik hastalığın varlığı ile zor entübasyon arasında istatistiksel olarak anlamlı bir ilişki vardı. YBÜ takibinin ana nedenleri yakın monitörizasyon ihtiyacı ve hava yolu ile ilişkili problemlerdi.

Sonuç: Zor hava yolu, eşlik eden tanılı bir sendromu olmasa bile YDD hastalarında sık görülebilen bir sorundur. Zor hava yolu veya postoperatif hava yolu obstrüksiyonu riski olan hastalar, deneyimli bir personel tarafından olası komplikasyonların hızlı teşhisi ve tedavisi için erken postoperatif dönemde yoğun bakımda daha iyi takip edilebilir.

Anahtar kelimeler: Hava yolu yönetimi, pediatrik anestezi, yarık damak ve dudak
Received/Geliş: 24 March 2020 Accepted/Kabul: 30 September 2020 Publication date: 29 January 2021

Cite as: Tümer M, Ayyıldız A, Akça B, et al. Perioperative complications and concomitant diseases of patients followed in intensive care unit after cleft lippalate surgery. JARSS 2021;29(1):65-70.

Murat Tümer Hacettepe Üniversitesi Tıp Fakültesi, Anesteziyoloji ve Reanimasyon Anabilim Dalı, Ankara, Türkiye

m.tumer@hacettepe.edu.tr ORCID: 0000-0001-9132-9992

A. Ayyıldız 0000-0002-8206-6921 Eskişehir Osmangazi Üniversitesi Tıp Fakültesi, Anesteziyoloji ve Reanimasyon Anabilim Dalı, Eskişehir, Türkiye

B. Akça 0000-0003-4069-2462 A. Ankay Yılbaş 0000-0001-6196-3191 F. Üzümcügil 0000-0001-9161-3248

Ö. Canbay 0000-0001-7645-4947 Hacettepe Üniversitesi Tıp Fakültesi, Anesteziyoloji ve Reanimasyon Anabilim Dalı, Ankara, Türkiye 


\section{INTRODUCTION}

Cleft lip/palate (CLCP), which is one of the most common craniofacial abnormalities seen worldwide (1), has been associated with about 300 anomalies up to now ${ }^{(2)}$. Pierre-Robin Sequence is one of the most associated anomalies and characterized by micrognathia, glossoptosis and cleft palate causing upper airway obstruction.

Patients with CLCP can be challenging even for experienced anesthesiologists. Morbidity is mostly associated with airway problems such as laryngospasm, bronchospasm, accidental extubation and airway obstruction ${ }^{(3,4)}$. Comorbidities and the risk of airway bleeding can make the situation more complex. These patients might need postoperative care in the Intensive Care Unit (ICU) depending on the experience of the team, age of the patient, comorbidities and airway problems ${ }^{(5)}$. Careful preoperative evaluation, close monitoring, planning of the postoperative ICU need and cooperation between all the team members including surgeons, anesthesiologists, nurses in the ICU or ward are important points for a safe perioperative period.

The aim of this study was to evaluate the factors (demographics, comorbidities, perioperative complications) associated with difficult airway and need for postoperative follow-up in ICU in CLCP patients operated in our institution.

\section{MATERIAL and METHOD}

After the approval of the local ethics committee, patients undergoing CLCP surgery in Hacettepe University Faculty of Medicine Hospital between September 2005 and September 2013 were examined retrospectively. The patients who were followed-up in ICU after surgery were included to the study. The design of the study was retrospective chart review. Data were collected from patient files, preoperative anesthesia evaluation forms, intraoperative anesthesia records, ICU nurse observation records and ICU doctor follow-up notes. Demographic data (age, sex, body weight), preoperative data (type of oral cleft, presence of micrognathia, concomitant diseases, congenital anomalies, history of previous surgery, and presence of previous airway problems), intraoperative data (presence of difficult mask ventilation and/or intubation, intubation technique, operation and anesthesia time, intraoperative complications) and postoperative data (indication for admission to ICU, extubation time and hospitalization time in the ICU, postoperative comp-lications) were examined for all patients. Operation time was defined as the time from the first incision to the last suture. Anesthesia time was defined as the time from the onset of mask induction to spontaneous eye-opening of the patient.

Our clinic has standardized anesthetic management for the patients undergoing CLCP surgery. Accordingly, we don't administer sedative as a premedication to patients with CLCP before surgery. Following standard monitoring in the operating room, anesthesia induction was performed with sevoflurane. A 24-gauge intravenous catheter was placed after patients lost consciousness and propofol $\left(1 \mathrm{mg} \mathrm{kg}^{-1}\right)$, fentanyl $\left(0.5 \mu \mathrm{g} \mathrm{kg}^{-1}\right)$, rocuronium bromide $(0.5 \mathrm{mg}$ $\left.\mathrm{kg}^{-1}\right)$, methylprednisolone (1-2 $\left.\mathrm{mg} \mathrm{kg}^{-1}\right)$ were administered intravenously. Two-handed mask ventilation technique was used for all patients. When muscle relaxation was adequate, endotracheal intubation was performed with suitable size and insertion depth of tracheal tubes. Direct laryngoscopy is used as routine tracheal intubation technique. Fiberoptic bronchoscopy was used as alternative technique in difficult intubation patients. The reason for choosing only fiberoptic bronchoscope as a standard alternative procedure was that any other indirect laryngoscopy devices were not available in our department at that time period. After intubation, anesthesia was maintained with $2 \%$ sevoflurane and $50 \%$ air in oxygen. Intraoperative analgesia was provided with remifentanil or dexmedetomidine infusion and paracetamol (7.5-15 mg kg-1 IV). Muscle relaxation was reversed with sugammadex (2-4 $\left.\mathrm{mg} \mathrm{kg}^{-1} \mathrm{IV}\right)$. Patients were extubated when spontaneous respiratory functions returned. All patients were followed up in the post-anesthesia recovery room (PAR) after the operation. Modified Aldrete's scoring system was used to decide the discharge of patients from PAR. Patients who needed postoperative maintenance in intensive care conditions were followed-up in ICU after surgery. The aim of this study was to evaluate the factors (demographics, comorbidities, perioperative complications) associated with difficult airway and 
M. Tümer et al. Perioperative Complications and Concomitant Diseases of Patients Followed in Intensive Care Unit After Cleft Lip-Palate Surgery

need for postoperative follow-up in ICU in patients with CLCP operated in our institution.

All analyses were performed using the Statistical Package for the Social Sciences (SPSS) version 11.5 (SPSS, Inc., Chicago, IL) statistical software. The values that were normally distributed were presented as means \pm standard deviation. Ordinal data were expressed as median (min-max). Categorical data were shown as number of cases and percentages. To compare the data in two groups, chi-square and Mann-Whitney $U$ test were used as statistical methods, where applicable. The Spearman correlation test was used to test whether there is a relationship between the data. A $p$ value $<0.05$ was considered statistically significant.

\section{RESULTS}

We could reach to the medical records of 682 patients undergoing cleft lip and palate surgery between 2005-2013. Thirty-eight patients were followed up in ICU after surgery. Of these patients, 18 were excluded from the study due to lack of medical records. A total of 20 patients followed up in PACU were included in the study.

Median age of patients was 10.5 (min 1-max 36$)$ months. Mean weight was $8.5 \pm 1.9$ ( $\min 4.3-\max 12)$ $\mathrm{kg}$. Ten patients ( 7 males, and 3 females) had cleft lip and palate, and 10 patients ( 7 males, and 3 females) had isolated cleft palate. There were no isolated cleft lip patients. Five patients had previous history of surgery and 3 patients had previous history of perioperative airway complications. Table I displays the demographic variables of patients.

Table I. Demographic variables

\begin{tabular}{lc}
\hline & $\mathbf{n}=\mathbf{2 0}$ \\
\hline Age (month) & $10.675 \pm 6.9855$ \\
Weight (kg) & $8.500 \pm 1.9391$ \\
Gender (f/m) & $6 / 14$ \\
CLP / CP / CL & $10 / 10 / 0$ \\
Concomitant Diseases (+/-) & $11 / 9$ \\
Congenital Anomalies (+/-) & $10 / 10$ \\
Micrognathia (+/-) & $16 / 4$ \\
Operation Time (min) & $124.5 \pm 42.3$ \\
Anesthesia Time (min) & $137.5 \pm 43.9$ \\
DI (+/-) & $8 / 12$ \\
DMV (+/-) & $1 / 19$
\end{tabular}

CLP: Cleft Lip and Palate, CP: Isolated Cleft Palate, CL: Isolated Cleft Lip, DI: Difficult Intubation, DMV: Difficult Mask Ventilation
Eleven patients had concomitant diseases. Cardiac anomalies were the most common concomitant diseases. Atrial septal defect (ASD) $(n=9)$ was the most frequent cardiac anomaly. Cerebral palsy, mental motor retardation, encephalocele, recurrent pulmonary infections, coloboma, cholelithiasis, hearing loss and chronic otitis media were the other systemic diseases. Ten patients had congenital anomalies. The most frequently seen congenital anomaly was Pierre-Robin Sequence $(n=5)$, followed by Treacher Collins ( $n=2)$, Goldenharr $(n=1)$, Rubenstein Taybi $(n=1)$ and $22 q 11$ del $(n=1)$ syndromes. Micrognathia was the most commonly associated anomaly $(n=16)$, congenital anomalies existed in 10 micrognathic patients.

Direct laryngoscope was the first-choice intubation device in 13 patients. Seven patients were intubated with fiberoptic bronchoscope through nasal route. Difficult intubation was seen in 8 patients ( 5 patients with isolated cleft palate, and 3 patients with cleft palate and lip). Difficult mask ventilation was seen only in one patient with 22q11 deletion, cleft lippalate, micrognathia and encephalocele.

All patients with difficult intubation were micrognathic but we could not find a statistically significant relationship between micrognathia and difficult intubation ( $p=0.117$ ). Nasal fiberoptic bronchoscopic technique was more commonly used in patients with difficult intubation $(p<0.001)$. Although difficult intubation was seen more frequently in patients with isolated cleft palate $(50 \%)$ than patients with cleft lip and palate (30\%); this difference was not statistically significant $(p=0.650)$. There was no statistically significant relationship between sex, age, weight and difficult intubation $(p=1.00 ; p=0.154 ; p=0.085$, respectively). Difficult intubation was seen more

Table II. Risk factors for difficult intubation

\begin{tabular}{lccc}
\hline & DI (+) $\mathbf{n = 8}$ & DI (-) $\mathbf{n = 1 2}$ & $\mathbf{p}$ \\
\hline Gender (m/f) & $6 / 2$ & $8 / 4$ & 1 \\
Age (month) & $13.4 \pm 9.4$ & $8,8 \pm 4,2$ & .154 \\
Weight (kg) & $9.4 \pm 1.79$ & $7.89 \pm 1.85$ & .085 \\
CP/CLP & $5 / 3$ & $5 / 7$ & .650 \\
Micrognathia (+/-) & $8 / 0$ & $8 / 4$ & .117 \\
Concomitant Diseases (+/-) & $7 / 1$ & $4 / 8$ & $.028^{*}$ \\
Congenital Anomalies (+/-) & $5 / 3$ & $5 / 7$ & .650 \\
\hline
\end{tabular}

${ }^{*} p<.05$ DI: Difficult Intubation, CL: Isolated Cleft Lip, CLP: Cleft Lip and Palate 
often in patients with congenital anomalies (50\%); however, this difference was not statistically significant $(p=0.650)$. There was a strong statistically significant relationship between the presence of any systemic disease and difficult intubation $(p=0.028)$. Risk factors of difficult intubation are given in Table II.

Mean operation time was $124.5 \pm 42.3(80-230) \mathrm{mi}-$ nutes. Mean anesthesia time was $137.5 \pm 43.9$ (min 90- max 240) minutes. Perioperative complications were seen in 3 patients (dyspnea after extubation in the operation room, $n=2$, and desaturation in the PAR, $n=1)$. The intubation of these patients was not difficult. The patient who desaturated in PAR was Pierre Robin sequence with isolated CL.

Eleven patients were extubated at the operating room; nine of whom were transferred to ICU just for the purpose of close monitoring and the reason for ICU stay was the presence of dyspnea following extubation in two patients. Nine patients were transferred to ICU as intubated for a planned weaning and extubation process for various reasons (difficult intubation, $n=6$, Goldenhar Syndrome, $n=1$, and 22q11del syndrome and difficult mask ventilation, $n=1$ ) except one patient who was re-intubated in the recovery room due to desaturation.

Seven of these 9 intubated patients were extubated in ICU within 24 hours. Postoperative extubation time was not found significantly related with operation time (The Spearman correlation coefficient $(r)$ $=0.175, p=0.460$ ) or anesthesia time (The Spearman correlation coefficient $(r)=0.223, p=0.345)$.

The median ICU hospitalization time was 24 ( $\min 8$ max 336) hours. Four patients stayed in ICU for longer than 24 hours. One of them had prolonged intubation due to surgical complications, one had fever and the other two patients stayed in ICU for more than 24 hours because of longer time requirement for extubation. ICU hospitalization time was not found significantly related to operation time (The Spearman correlation coefficient $(r)=0.271$, $p=0.249$ ), anesthesia time (The Spearman correlation coefficient $(r)=p=0.161)$, the presence of concomitant diseases (ranked T-test $p=0.229$, Cohen's $d$ : 0.555 ) and syndromes (ranked T-test $p=0.580$, Cohen's d: 0.267). Complications seen in ICU were fever ( 2 patients) and incisional damage (the patient who had prolonged intubation).

\section{DISCUSSION}

The outcomes of our analysis demonstrated that the most convincing part of the anesthetic procedure during CLCP surgery is airway management which is frequently difficult in relationship with numerous syndromes. Even without a diagnosed syndrome, these patients may still have a syndromic face, micrognathia and difficult airway. In the situation of difficult intubation, admittance to ICU should be assessed for delivering secure and ideal conditions for extubation as well as for close monitoring after extubation.

Demographic data of the patient group that we evaluated in our study were similar to the general patient population. In literature, isolated cleft palate is the abnormality mostly accompanied by other syndromes ${ }^{(6-8)}$. In our study, $50 \%$ of the patients with isolated cleft palate were associated with a syndrome, most commonly Pierre-Robin Sequence $(n=5,25 \%)$. Micrognathia was the most common anomaly accompanying cleft lip and palate in 16 patients (80\%).

Being less than 1 year old and having craniofacial abnormalities increase the risk of difficult intubation in pediatric patients ${ }^{(9)}$. In our study, isolated $\mathrm{CP}$, micrognathia and congenital anomalies were apparently related with difficult intubation. But there was no statistically significant relationship between them. We attribute this to the small number of patient groups. There was a statistically significant relationship between difficult intubation and presence of any systemic diseases $(p=0.028)$.

Videolaryngoscopy and fiberoptic bronchoscopy are common intubation techniques in CLCP cases where difficult intubation is anticipated ${ }^{(10)}$. In our study, mostly used intubation methods were direct laryngoscopy and fiberoptic bronchoscopy performed through nasal route. During the study period, videolaryngoscopy was not a widely used intubation method in our hospital due to lack of equipment. However, nowadays, we often use videolaryngoscopy in difficult intubation cases in our clinic. Videolaryngoscopy is a beneficial, safe and easy 
M. Tümer et al. Perioperative Complications and Concomitant Diseases of Patients Followed in Intensive Care Unit After Cleft Lip-Palate Surgery

method proven to improve laryngoscopic view with higher first-pass success rates in pediatric patients. Although fiberoptic bronchoscopy is still the goldstandard method for difficult airway patients, the technique of intubation should be based on the experience of anesthesiologists, the etiology of difficult airway and the conditions of each institution.

Most of the ICU indications in the first 24 hours of patients undergoing CLCP surgery are airway problems due to surgical procedures ${ }^{(11)}$. Our patients had also similar indications for ICU follow-up. Eleven of the patients (nine of them were intubated) were admitted to ICU due to airway problems. However, nine patients were admitted to ICU for close monitoring following difficult airway management or due to possible risk of airway obstruction even if they had no related complications with the intention to provide close monitoring and appropriate airway management in case of emergency. We think that the monitoring conditions should be determined according to the conditions of each country and medical center.

ICU nurses and doctors should be properly informed about the surgical procedure, whether the patient has a syndrome, difficult airway history, known allergies, local or regional applied block agents, analgesic drugs administered, and patient status during surgery. Nurse evaluation is very important in terms of possible complications in the acute postoperative period. Airway obstruction, hemorrhage, separation of palate, foreign body aspiration and laryngeal spasm are complications that can occur in the postoperative period after extubation ${ }^{(12)}$. Early postope-rative hypoxemia is a common problem in patients receiving general anesthesia. In a study conducted by Xue et al. ${ }^{(13)}$ in pediatric patients who underwent elective plastic surgery, it was reported that early postoperative hypoxemia was more common in children undergoing palate repair than in other surgical operations. We also re-intubated one isolated $\mathrm{CP}$ case with Pierre Robin Sequence in the recovery room due to postoperative hypoxemia and monitore the patient in ICU afterwards. In our study, the only complications seen in ICU were fever and incisional damage, all the extubations performed in ICU were eventless.

\section{CONCLUSION}

Airway problems and the need for close monitoring were the main reasons for postoperative ICU followup in CLCP patients in the current study. Although small sample size and retrospective design were the major limitations and there is still need for further research, we recommend that patients with difficult airway or risk of postoperative airway obstruction can be better monitored in ICU during early postoperative period for rapid diagnosis and treatment of possible complications by experienced staff.

Ethics Committee Approval: Hacettepe University Faculty of Medicine (12.06.2013)

Conflict of Interest: None

Funding: None

Informed Consent: Obtained

\section{REFERENCES}

1. Sharif F, Mahmood F, Azhar MJ, et al. Incidence and management of cleft lip and palate in Pakistan. JPMA - The Journal of the Pakistan Medical Association. 2019;69:632-9.

2. Leslie EJ, Marazita ML. Genetics of cleft lip and cleft palate. Am J MEd Genet Part C Semin Med Genet. 2013;163C:246-58. https://doi.org/10.1002/ajmg.c.31381

3. Jackson O, Basta M, Sonnad S, Stricker P, LaRossa D, Fiadjoe J. Perioperative risk factors for adverse airway events in patients undergoing cleft palate repair. The Cleft Palate-Craniofacial Journal. 2013;50:330-6. https://doi.org/10.1597/12-134

4. Mukozawa M, Kono T, Fujiwara S, Takakura K. Late onset tongue edema after palatoplasty. Acta Anaesthesiologica Taiwanica. 2011;49:29-31. https://doi.org/10.1016/j.aat.2011.01.004

5. Brailsford J, Smith D, Lizarraga A, Bermudez L. Surgical management of patients with cleft palate. Or Nurse. 2010;4:16-25. https://doi.org/10.1097/01.ORN.0000372493.61514.da

6. Mossey PA, Modell B. Epidemiology of oral clefts 2012: an international perspective. In: Cobourne MT, editor. Cleft Lip and Palate. Epidemiology of oral clefts 2012: an international perspective. London: Karger Publishers; 2012. pp.1-18. https://doi.org/10.1159/000337464

7. Rittler M, Cosentino V, López-Camelo JS, Murray JC, Wehby G, Castilla EE. Associated anomalies among infants with oral clefts at birth and during a 1-year follow-up. Am J Med Genet Part A. 2011;155:1588-96. https://doi.org/10.1002/ajmg.a.34046

8. Adesina OA, Efunkoya AA, Olaitan A, Adesina OO. Associated anomalies in cleft lip and palate: analysis of 811 consecutive patients. South Sudan Medical Journal. 2017;10:60-3.

9. Heinrich S, Birkholz $T$, Ihmsen $H$, Irouschek $A$, 
Ackermann A, Schmidt J. Incidence and predictors of difficult laryngoscopy in $\mathbf{1 1 . 2 1 9}$ pediatric anesthesia procedures. Pediatric Anesthesia. 2012;22:729-36. https://doi.org/10.1111/j.1460-9592.2012.03813.x

10. Brzenski A, Ham-Mancilla O, Peña-Olvera S, Gosman A, Sigler A. Pediatric Anesthesia for Patients with Cleft Lip and Palate. In: Whizar-Lugo VM, editor. Anesthesia Topics for Plastic and Reconstructive Surgery. Intech Open; 2018.

https://doi.org/10.5772/intechopen.74926

11. Raghavan U, Vijayadev V, Rao D, Ullas G. Postoperative management of cleft lip and palate surgery. Facial
Plastic Surgery. 2018;34:605-11.

https://doi.org/10.1055/s-0038-1676381

12. Apfelbaum JL, Hagberg CA, Caplan RA, et al. Practice guidelines for management of the difficult airway an updated report by the American Society of Anesthesiologists task force on management of the difficult airway. Anesthesiology. 2013;118:251-70. https://doi.org/10.1097/ALN.0b013e31827773b2

13. Xue FS, Huang YG, Luo LK, et al. Observation of early postoperative hypoxaemia in children undergoing elective plastic surgery. Pediatric Anesthesia. 1996;6:21-8. https://doi.org/10.1111/j.1460-9592.1996.tb00347.x 